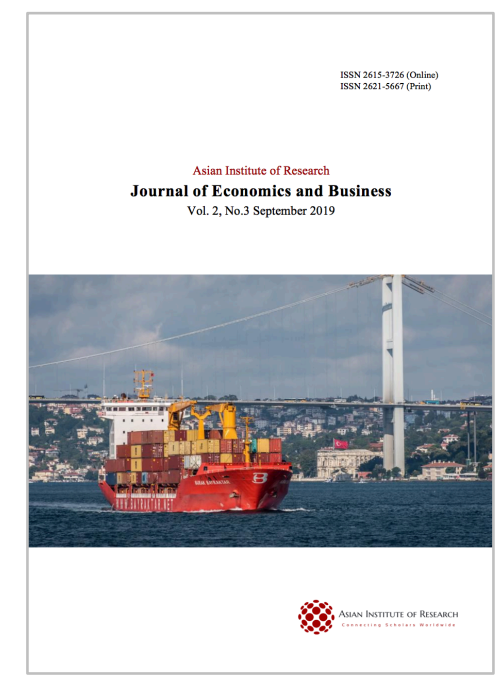

\title{
Journal of Economics
} and Business

\author{
Amuka, Joseph I, Asogwa, Fredrick O, Ezeudeka, Chukwudi F, Ugwuanyi, \\ Romanus O, and Onyechi, Tochukwu. (2019), What Drives Inclusive Growth? \\ Evidence from Georgia. In: Journal of Economics and Business, Vol.2, No.3, 883- \\ 890.
}

ISSN 2615-3726

DOI: 10.31014/aior.1992.02.03.135

The online version of this article can be found at: https://www.asianinstituteofresearch.org/

Published by:

The Asian Institute of Research

The Journal of Economics and Business is an Open Access publication. It may be read, copied, and distributed free of charge according to the conditions of the Creative Commons Attribution 4.0 International license.

The Asian Institute of Research Journal of Economics and Business is a peer-reviewed International Journal. The journal covers scholarly articles in the fields of Economics and Business, which includes, but not limited to, Business Economics (Micro and Macro), Finance, Management, Marketing, Business Law, Entrepreneurship, Behavioral and Health Economics, Government Taxation and Regulations, Financial Markets, International Economics, Investment, and Economic Development. As the journal is Open Access, it ensures high visibility and the increase of citations for all research articles published. The Journal of Economics and Business aims to facilitate scholarly work on recent theoretical and practical aspects of Economics and Business. 


\title{
What Drives Inclusive Growth? Evidence from Georgia
}

\author{
Joseph I. Amuka ${ }^{1}$, Fredrick O. Asogwa ${ }^{2}$, Chukwudi F. Ezeudeka ${ }^{3}$, Romanus O. Ugwuanyi ${ }^{4}$, Tochukwu Onyechi ${ }^{5}$ \\ 1,2,5 Department of Economics, University of Nigeria Nsukka \\ ${ }^{3}$ Federal Inland Revenue Services, Abuja-Nigeria \\ ${ }^{4}$ Institute Development Studies, University of Nigeria Enugu Campus
}

Corresponding Author: Joseph I. Amuka, Department of Economics, University of Nigeria Nsukka, email: dobuamuka@gmail.com

\begin{abstract}
Inclusive growth is the current debate in development economics because it is seen as central to sustainable economic growth and development. Georgia is one country where growth seems to have been inclusive among the emerging economies. This stimulated a research interest. The paper used growth model and dynamic ordinary least squares method to analyse the Determinants of Inclusive Growth, using Georgia data generated from World Bank Development Indicators between 1996 and 2016. Result shows that growths in industrial and service sectors were significantly responsible for rise in the income share of the poorest and richest income group in Georgia.
\end{abstract}

Keywords: Drives, Inclusive Growth, Evidence, Georgia

\section{Introduction}

Inclusive growth is the current topic of discussion because it is believed that the world will be a better place to live if benefits of growth can go round to every member of the society. But, observation shows that in the majority of the countries in the last two decades, growth benefitted only the rich and widened inequality (Organization for Economic Coo-operation and Development (OECD, 2012). For instance, in a random selection of 10 emerging economies between 1984 and 2016, inequality widened in Bangladesh, Nigeria, Bolivia, South Africa, Costa Rica, and Botswana. The countries where inequality narrowed are Malaysia, Chile, Brazil, and Mexico (World Bank, 2018). Lopsided pattern of growth can create a crisis in a country because the people below the minimum acceptable standard of living can rise up against the state any day (Ortiz and Cummins, 2011).

The definition of inclusive growth cuts across individual scholars and institutions. Hirway (2011) defined inclusive growth as that growth which can open opportunity for the excluded and marginalized groups in a society, and Zhuang and Ali (2010) narrowed their definition to the growth which can create economic opportunity for every citizen and lead to a decline in inequality of opportunity. According to Samans et al. 
(2015), inclusive growth is the reduction in inequality as the output of an economy grows. On the side of institutions, inclusive growth is the growth that can reduce poverty very fast and at the same time, reduce inequality across income groups (United Nations Development Programme, UNDP, 2011). In the definition given by Asian Development Bank (ADB, 2011), it is that growth which can bring a rise in output and opportunity to the people such that both the poor and the rich derive benefits as the economy grows.

Moreover, Organization for Economic Co-operation and Development (OECD, 2014) points out that inclusive growth is the growth that can create opportunity for all to bring fairly distribution of benefits of economic prosperity in an economy both in monetary and non-monetary terms. The definition given by Anand, Mishra, and Peiris (2013) seems to be more concise. According to Anand, Mishra, and Peiris, inclusive growth means the growth that leads to a faster increase in the income of the poor than that of the rich in real terms, with an obvious reduction in the level of inequality. In this definition, Anand, Mishra, and Peiris made the point clear that the benefits of growth that go to the poor in a real term must be more than the benefits that go to the rich before inequality can fall.

The way inclusive growth is defined as matters for an empirical investigation. For the present study, we take inclusive growth as defined by Anand, Mishra, and Peiris (2013) which is the growth capable of raising the income share of the poor more than that of the rich. There are three main reasons why we are adopting it. One, Sembene (2015) used the same definition in a cross-country study of sub-Saharan African and other countries of Asia. Two, the definition sees inclusive growth beyond addressing inequality problem because inequality can even fall without growth or growth can reduce inequality in a way that is harmful. For example, growth that raises the income of the poor and reduces the income of the rich has reduced inequality. However, the reduction in inequality, in this case, created some disincentives to a group which can harm future growth. Three, adopting the definition will make the statistical estimation easy.

Development indicators show that Georgia is the only fast-growing economy which may have experienced inclusive growth in more than two decades (World Bank, 2018). The share of the lowest 10 percent income group in the country rose from 2.3 percent in 1996 to 2.6 percent in 2016. It indicates that the share of the poorest group from the national income increased by 0.3 percent. Similarly, the share of the highest 10 percent income group rose from 27.9 percent in 1996 to 28.1 percent in 2016. This indicates that the income share of the richest 10 percent income group in the economy increased by 0.2 percent. From the change in income of the poorest and richest group, growth in Georgia between 1996 and 2016 satisfied the necessary and sufficient conditions of inclusiveness because its benefit went to the poorest more than the richest group.

Economic performance of Georgia has been impressive since 1995. Outside 2009, the country recorded positive growth between 1995 and 2016 (World Bank, 2018). With the benefits of growth trickling down to the poorest group more than the richest in Georgia, the country achieved the feet which none of the fast-growing economies of China and Malaysia was able to achieve. The achievement motivated the authors' interest to examine the factors which led to inclusive growth in Georgia so that other developing countries can emulate.

\section{The Theory and Related Literature}

Debates in economic literature have centred on growth since the time of the mercantilist and the early classical scholars. The debate will likely continue and may only end with man. This is because growth and development are the very essence of life of every individual or the society in which the individual lives. As far as there are unsatisfied needs and inequality exists in the society, the one below the measurement ladder will continue striving to catch-up the one on top of the ladder. It is the struggle for equality that creates inequality. Theories of growth evolved over time, and like theories in other academic discipline, some of them have been challenged by the dynamics of world economic development.

Early scholars of economics were interested in the growth of the national economy, and every discussion was on what can lead to an improvement in the national income. Adam Smith directed his effort to the wealth of the nation and built his theory around free trade and specialization based on absolute advantage. He argued that 
when every nation specializes in the production of the commodity, she has an absolute advantage in production and import the one she has an absolute disadvantage in production; the output of that country will increase because she will direct her resources in producing only the commodity she is better suited for. In addition, the process will lead to an increase in world output as well as benefits to all. Unfortunately, the absolute advantage did not bring a fair distribution of income across income groups.

The theory of socialism which came up in the early twentieth century was a revolution against widening income inequality and class exploitation. Karl Marx, who propounded the theory, pointed out that the evil of capitalism is class exploitation. Marx asserts that the capitalist pay workers less than what they contributed in the production process only to exploit them. The Marxian theory of socialism led to class struggle and revolution in some parts of Europe and Asia in the early twentieth century. The socialist revolution led to a change in development thinking towards the challenges of inequality and the need to fight poverty. As a result, the theory of socialist system which placed ownership and distribution of wealth on the state emerged in the early twentieth century.

Socialism succeeded in narrowing class inequality but slowed productivity and growth. For example, economic prosperity was slower in the former Union of Soviet Socialist Republic (USSR) and the People's Republic of China where socialism was practiced when compared with the United States of America where capitalism was practiced. Socialism as a theory had become less popular in economic thinking since the early 1990s when the Union of Soviet Socialist Republic collapsed, and the component states, as well as China, opened up their economies to the outside world. Simon Kuznets (1955) pioneered research on the relationship between economic growth and income inequality. The result of Kuznets' study showed an inverted U-curve relation between economic growth and income inequality. Precisely, the study revealed that at the initial stage of a country's economic development, inequality increases with growth, and later, inequality falls as growth continues.

The outcome of Kuznets' work led to the emergence of some other theories of growth and poverty. The sustainable growth theory posits that growth creates employment, and employment creates income which reduces poverty. Karnani (2011) points out that steady employment is the easiest way to move people out of poverty. Scholars like Dursun and Ogunleye (2016) found a positive impact of growth on poverty reduction as well as a negative relationship between employment and poverty. However, Son and Kakwani (2004), in their study, revealed that growth could reduce poverty if the level of inequality in an economy is low. Poverty is the developing countries' challenge. Despite measures such as social intervention taken in the past to checkmate it, it has remained in many developing countries. Studies by Potts (2012), and Baum, Mshvidobadzo and Tsuruoka (2015) showed evidence that poverty reduction strategy like cash transfer can lead to a disincentive to work as the poor develop a poor attitude to work.

Inclusive growth is indispensable in the fight against poverty. Unfortunately, studies are scanty in the area. The known studies here include Sembene (2015) and Ibukun and Aremu (2016). Evidence from the study by Sembene revealed that implementation of the poverty reduction strategy in sub-Saharan Africa and some other countries outside Africa did not lead to inclusive growth. Study in Nigeria by Ibukun and Aremo had a methodological problem because they used per capita income as a proxy for inclusive growth. However, scholars like Nagaraj (2012), Ogujiuba and Alehile (2011), Hull (2009), and Islam (2014) have pinpointed the factors that can lead to inclusive growth. They highlighted the importance of job creation in the sectors that drive the growth and the need to make inclusive policy such as reform in education and health as the factors that can make growth inclusive.

These scholars argue that poor skill is a limiting factor to labour market opportunities and if the state increases investment in education, the poor can take advantage of it to get trained according to the skill needs of the modern economy. Zhuang and Ali (2010) and Canlas (2016) equally hold the same view that access to education is very important in the achievement of inclusive growth because the poor cannot benefit from the opportunities the labour market provides until they acquire the right skill. The opinion is in line with the view of Chenery et al. (1979) who suggested that government should invest in education specifically targeted at the poor as a 
development policy in developing countries because it is the major source of human capital development which the poor need in order to reap the benefit of growth.

Moreover, Jeong (2005) and United Nations Development Programme (UNDP, 2014) maintained that the linkage between the sector which drives growth and the sector where the poor works play a major role in propelling inclusive growth. Jeong points out that occupational transformation takes places as the tempo of industrialization rises, paving the way for labour to migrate from agriculture to the industry. And for growth to be inclusive, agriculture and the industry must be linked so that a great number of the poor will be able to move from the agricultural activity to the industry. On the other hand, the position of Anand, Mishra, and Peiris (2013) is that the pattern of growth is important in bringing inclusiveness. According to them, when growth takes place in such a way that it increases the income of the poor more than that of the rich, it will be inclusive. But when growth increases the income of the rich more than that of the poor, inequality will widen, and growth will not be inclusive.

With the above literature reviewed, the determinant of inclusive growth has not been done in Georgia to the best of the knowledge of the authors. Georgia experienced inclusive growth between 1996 and 2016 (World Bank development indicators, 2018), and a study like this will benefit many developing countries. The present study will fill the gap in the literature, and the outcome will be of the great lesson to other developing countries.

\section{The Model}

We specify an exogenous growth model which operates within the framework of the neoclassical economists and can be applied in the dynamic ordinary least squares estimation method. We follow the Solow-Swan growth model, which explains long-run economic growth using capital, labour, and technological progress. Accordingly,

$$
Y(t)=k(t)^{\alpha}\left(A(t) L(t)^{1-\alpha}\right.
$$

Where: $\mathrm{t}=$ time,

$0<\alpha<1=$ elasticity of output accrued to capital, $\mathrm{Y}(\mathrm{t})=$ total output, $\mathrm{A}$ is labour-augmenting technology,and $\mathrm{AL}$ is the effective labour in the model of Georgia economy within the period of study. The effective labour (AL) grows at $\mathrm{D}+\mathrm{g}$ while capital depreciates at $\delta$, Hence, the derivative of $\mathrm{K}$ with respect to time becomes

$$
\mathrm{K}^{\prime}(\mathrm{t})=\mathrm{s}^{*} \mathrm{Y}(\mathrm{t})-\delta * \mathrm{~K}(\mathrm{t})
$$

The golden rule savings rate of the Solow-Swan maintains that the capital/output ratio is solely a function of savings at the equilibrium. $\mathrm{K}$ ' is inversely related to capital labour ratio since $\alpha$ is less than 1 at any time $\mathrm{t}$.

$$
M P K=\frac{\partial Y}{\partial K}=\frac{\alpha A^{1-\alpha}}{\left(\frac{K}{L}\right)^{1-\alpha}}
$$

Equation 3 shows that a country with less $\mathrm{K} / \mathrm{L}$ will get a higher marginal product which provides a higher return on capital, that is, the inflow of investment from rich country to poor countries.

The model for this study is the income share function using data from Georgia. The model is designed to capture the impact of such change in some sectors of the economy of Georgia on the income share of the lowest and the highest $10 \%$ group.

$$
\mathrm{YS}_{\mathrm{L}, \mathrm{H}}=\mathrm{f}(\mathrm{HC}, \mathrm{AGG}, \mathrm{EMP}, \mathrm{INDG}, \mathrm{GRS})
$$

Where: $\mathrm{YS}=$ Income share $\left(\mathrm{YS}_{\mathrm{L}}=\right.$ income share of the loweat $10 \%$ and $\mathrm{YS}_{\mathrm{H}}=$ income share of the highest $\left.10 \%\right)$, $\mathrm{HC}=$ human capital development, EMP $=$ employment, $\mathrm{AGG}=$ Growth in Agriculture, $\mathrm{INDG}=$ Growth in Industrial sector and GRS $=$ Growth in services. 
Equation 4 captures the behaviour of income share by the lowest and highest $10 \%$ income group in Georgia.

For estimation, equation 4 is specified econometrically-

$$
Y S_{t}=\alpha+\beta_{1} H C_{t}+\beta_{2} A G G_{t}+\beta_{3} E M P_{t}+\beta_{4} I N D_{t}+\beta_{5} G R S_{t}+e_{t}
$$

Where

$\alpha=$ intercept. $\beta_{1}-\beta_{5}=$ coefficients, $\mathrm{e}=$ error, and $\mathrm{t}=$ time to denote time series. Other variables are as defined before.

Equations 4 and 5 can be specified as

$$
Y_{i t}=\propto_{i}+\beta_{i X_{i t}}+e_{i}
$$

where: $Y_{t}$ represents the income share of the lowest or highest $10 \%$ in Georgia, $X_{t}$ is made up of all the explanatory variables as described in the model; $\mathrm{e}_{\mathrm{i}}$ is the error term.

Data

Data for the study were obtained from the World Bank Development Indicators (2018) between 1996 and 2016.

\section{Result}

The results of the analyses are presented in tables 1-4 below

Table1: Unit Root Test

\begin{tabular}{|l|l|l|l|}
\hline Variable & ADF & $5 \%$ & Order of Integration \\
\hline YS $_{\mathrm{H}}$ & -8.944510 & -2.897223 & $\mathrm{I}(1)$ \\
\hline $\mathrm{YS}_{\mathrm{L}}$ & -11.42059 & -2.898623 & $\mathrm{I}(1)$ \\
\hline AGG & -8.680164 & -2.900670 & $\mathrm{I}(2)$ \\
\hline EMP & -8.948968 & -2.897223 & $\mathrm{I}(1)$ \\
\hline GRS & -9.312128 & -2.897223 & $\mathrm{I}(1)$ \\
\hline HC & -6.547406 & -2.900670 & $\mathrm{I}(1)$ \\
\hline INDG & -12.76576 & -2.898623 & $\mathrm{I}(2)$ \\
\hline
\end{tabular}

Source: analysis using Georgia data

Table 1 is the result of the unit root test for the stationary level of the variables. Industrial and agricultural growths are stationary at the second difference, while the rest are integrated at the first difference. Regression without unit run test is not always reliable because the result may be spurious (Baltagi, 2001).

Table 2a: Result of Structural Equation (dependent variable= lowest $10 \%$ group)

\begin{tabular}{|l|l|l|l|l|}
\hline Variable & Coeff & Std error & t-value & prob \\
\hline C & 2.448535 & 3.547378 & 0.69 & 0.4921 \\
\hline AGG & -0.092621 & 0.011736 & -7.89 & 0.0000 \\
\hline EMP & -0.035880 & 0.016107 & -2.23 & 0.0288 \\
\hline GRS & -0.127808 & 0.018726 & -6.83 & 0.0000 \\
\hline HC & 0.071051 & 0.032788 & 2.17 & 0.0333 \\
\hline INDG & 0.136307 & 0.026642 & 5.12 & 0.0000 \\
\hline R2 & & & & 0.610529 \\
\hline F-stat & & & & 24.45435 \\
\hline Pr(F-sta) & & & & 0.000000 \\
\hline Sourc: anlys
\end{tabular}

Source: analysis of Georgia data

Table 2b: Result of structural model (dependent variable $=$ highest $10 \%$ income group)

\begin{tabular}{|l|l|l|l|l|}
\hline Variable & Coeff & Std error & t-value & prob \\
\hline C & -40.64434 & 18.82521 & -2.16 & 0.0339 \\
\hline AGG & 0.523359 & 0.062281 & 8.403200 & 0.0000 \\
\hline
\end{tabular}




\begin{tabular}{|l|l|l|l|l|}
\hline EMP & 0.286021 & 0.085477 & 3.346196 & 0.0013 \\
\hline GRS & 0.789003 & 0.099377 & 7.939465 & 0.0000 \\
\hline HC & 0.150105 & 0.173998 & 0.862684 & 0.3910 \\
\hline INDG & -0.542198 & 0.141384 & -3.83 & 0.0003 \\
\hline$R^{2}$ & 0.513235 & & & \\
\hline F-stat & 16.44835 & & & \\
\hline Pr(F-sta) & 0.000000 & & & \\
\hline
\end{tabular}

Source: analysis using Georgia data

Table $2 a$ and $2 b$ are the analysis without due consideration of the stationary level of the data. The purpose of the analysis is for reference in further transformation.

Table 3a: Result of Dynamic Equation (dependent variable= lowest 10\% income group)

\begin{tabular}{|l|l|l|l|l|}
\hline Variable & Coeff & Std error & t-value & prob \\
\hline $\mathrm{C}$ & 0.011379 & 0.009208 & 1.24 & 0.2203 \\
\hline $\mathrm{D}(\mathrm{D}(\mathrm{AGG}))$ & 0.005452 & 0.007394 & 0.74 & 0.4632 \\
\hline $\mathrm{D}($ EMP) & -0.025522 & 0.012280 & -2.08 & 0.0411 \\
\hline $\mathrm{D}(\mathrm{GRS})$ & -0.039408 & 0.011416 & -3.45 & 0.0009 \\
\hline $\mathrm{D}(\mathrm{HC})$ & 0.021987 & 0.021094 & 1.04 & 0.3006 \\
\hline $\mathrm{D}(\mathrm{D}(\mathrm{INDG}))$ & 0.042148 & 0.013778 & 3.06 & 0.0031 \\
\hline $\mathrm{R}^{2}$ & 0.26 & & & \\
\hline F-stat & 5.349021 & & & \\
\hline Prob(F-stat & 0.000289 & & & \\
\hline
\end{tabular}

Source: analysis of Georgia data

Table 3b: Result of Dynamic Equation (dependent variable= highest 10\% income group)

\begin{tabular}{|l|l|l|l|l|}
\hline Variable & coeff & Std err & t-value & prob \\
\hline $\mathrm{C}$ & -0.044283 & 0.049417 & -0.90 & 0.3730 \\
\hline $\mathrm{D}(\mathrm{D}(\mathrm{AGG}))$ & -0.002294 & 0.039680 & -0.06 & 0.9540 \\
\hline $\mathrm{D}(\mathrm{EMP})$ & 0.121536 & 0.065903 & 1.84 & 0.0691 \\
\hline $\mathrm{D}(\mathrm{GRS})$ & 0.218804 & 0.061266 & 3.57 & 0.0006 \\
\hline $\mathrm{D}(\mathrm{HC})$ & 0.087118 & 0.113206 & 0.77 & 0.4440 \\
\hline $\mathrm{D}(\mathrm{D}(\mathrm{INDG}))$ & -0.153573 & 0.073941 & -2.08 & 0.0412 \\
\hline $\mathrm{R}^{2}$ & 0.22 & & & \\
\hline F-stat & 4.340485 & & & \\
\hline Prob(F-stat & 0.001580 & & & \\
\hline
\end{tabular}

Source: analysis using Georgia data

Result in table $3 \mathrm{a}$, and $3 \mathrm{~b}$ are very important because the analyses were done, taking into consideration the stationary levels of the data. In table $3 a$, all the variables in the equation turned out with the expected sign except employment generation. Human capital development, agriculture, and industrial growth have a positive effect on the income share of the poorest group in Georgia. Industrial growth was the significant factor that led to the increase in income share of the bottom $10 \%$ group in the country within the period of analysis. When the industrial sector grows by a percent, the income share of the bottom $10 \%$ income group will rise by 0.04 percent. The result supports the argument that as an economy grows, the poor migrates from poor paying agriculture sector to industry where the condition of work is better (Jeong, 2005). Moreover, employment and growth in the service sector had a significant reduction in the income share of the poorest group.

In table $3 \mathrm{~b}$, agricultural growth has a negative effect on the income share of the highest $10 \%$ income group. This is expected because the agricultural sector in the majority of the countries of the world is dominated by the lower-income group. The growth of the service sector is highly significant and is the major contributor to the increases in the income share of the highest 10\% income group between 1996 and 2016. From the coefficient, a percent growth in the service sector will lead to 0.22 percent increase in the income share of the richest $10 \%$ income group in the country.

\section{Discussion of Finding}


The focus of the research is on the determinants of inclusive growth with reference to Georgia. The interest shown in the area and with particular reference to Georgia is because thorough examination of World Bank Development Indicators (2018) reveals that the country is the only emerging economy which experienced inclusive growth in the last two decades. Moreover, sustainable development will be difficult to achieve in developing countries if growth is not inclusive. Inclusive growth portends that almost everyone is on board of the ship as the economy moves forward in a more progressive direction.

There are two surprises in the result presented in table 3a judging by theory. The presented result reveals agricultural is not a significant factor that had led to the inclusive growth in Georgia between 1996 and 2016. The turnout of the result is surprising because it is assumed that the majority of the poor earn their living working in that sector, and any progress in the sector will be of high benefit to them. However, it may be that the growth in the sector within the period of study was not large enough to generate a significant effect on the income share of the poorest group. The second surprise is the negative effect of unemployment on the income share of the poorest group. There can be only one explanation to that. Employment pattern in Georgia showed job growth was mainly in the service sector between 1996 and 2016 (World Bank, 2018). As we know, the majority of the poorest people are always with low skill and may not fit well in the service sector where employment grew most.

Moving down to the industrial sector, the sector is the main significant source of inclusive growth between 1996 and 2016 in Georgia. There are two reasons to explain this. One, there may be a strong link between agriculture and industrial sector in Georgia so that growth in the industrial sector had a multiplier effect in the agricultural sector. Two, there may have been the migration of poor workers from the agricultural to the industrial sector due to industrial expansion. One of the two developments may have taken place, or the two may have happened together (Jeong, 2005; United Nations Development Programme (UNDP), 2014).

As we turn our attention to the richest group in table $3 \mathrm{~b}$, the service sector is the only factor that led to the significant increase in the income share of the richest 10 percent group in Georgia between 1996 and 2016. Growth in the industrial sector reduced the share of the richest people significantly. With the exception of human capital, all the factors which are anti-poor are pro-rich. For instance, when the industrial sector is growing the poor benefits and the rich looses and when the service sector is growing the rich benefits and the poor looses. This has an important implication for policy making because it shows that pursing industrial growth policy will hurt the richest people, and pursuing service growth policy will hurt the poorest group.

\section{Conclusion}

Inclusive growth is the way forward to achieve sustainable development because it means almost everyone is going to be on board of the ship of development. To achieve this in developing countries is not going to be a mean task. It needs discipline and dedication on the part of every citizen because growth comes through hard work and dedication to duty. The study investigated the factors that led to inclusive growth in Georgia for other developing countries to learn. Sincerely, growth taking place in an inclusive manner is not an easy one going by the definition. This is why Georgia was the only country which has experienced it among the growing economies from the knowledge of the authors. Georgia needs to strengthen industrial growth policy to continue reaping the benefits of inclusive growth and reduction in inequality.

\section{Reference}

Anand R.S, S Mishra, and SJ Peiris (2013) Inclusive Growth: Measurement and Determinants. IMF Working Paper 13/135

Asian Development Bank (ADB, 2011) Framework of Inclusive GrowthIndicators: Key Indicators for Asia and the Pacific. (Special Supplement).

Baltagi B. (2001) A Companion to Theoretical Econometrics. Blackwell Publishing

350 Main Street, Malden, MA 02148-5018, USA 108 Cowley Road, Oxford OX4 1JF, UK

Baum M.; A. Mshvidobadze and H. Tsuruoka (2015) Reducing Child Poverty in Georgia: A 
Way Forward, United Nations Children's Fund

Canlas B. (2016) Investing in Human Capital for Inclusive Growth: Focus on Higher Education. Philippine Institute for Development Studies, Discussion Paper No.2016-02.

Chenery H., MS Ahuwalia, CLG Bell, LJH Duloy and R Jolly (1979) Redistribution with Growth. Published for the World Bank and the Institute of Development Studies University of Sussex Oxford University Press.

Dursun G. and B Ogunleye. (2016) Economic Growth, Employment and Poverty Reduction: The Case of West African Countries. American Journal of Economics 6(1): 50-60

Hirvay I (2011) Consultation on Conceptualizing Inclusive Growth, in United Nations

Development Programme 2011ed, Conceptualizing Inclusive Growth. Discussion in a Two-Day Workshop on Inclusive Growth organized by United Nations Development Programme and India Planning Commission October 24-25. New Delhi, India

Hull K (2009) Understanding the Relationship between Economic Growth, Employment and Poverty Reduction. In OECD (2009 ed) Promoting Pro-Poor Growth: Employment. Economic Growth, Employment and Poverty Reduction P69-94.

Ibukun CO, AG Aremo (2016) Determinants of Inclusive Growth in Nigeria: An ARDL Approach. American Journal of Economics; 7(3): 97-109

Islam R (2014) Human Capital and Inclusive Growth: The Challenge for Bangladesh.

Working Paper on Vision 3030 and Framework for Economic making and Strategy formation in a Pluralistic Democracy, held in Dhaka, Senegal, 21-22 June 2014

Jeong H. (2005) Assessment of Relationship between Growth and Inequality: Micro Evidence from Thailand. Institute of Economic Policy Research, Working Paper No.20

Karnani A. (2011) Reducing Poverty through Employment. Innovations 6( 2) p73-97

Kuznets S. (1955) Economic Growth and Income Inequality. The American Economic Review, Vol.XLV(45) NO.1, P1-28.

Nagaraj R. (2012) Growth, Inequality and Social Development in India: Is Inclusive Growth Possible? Development Pathways to Poverty Reduction, United Nations Research Institute for Social Development (UNRISD), Palgrave, Macmillan.

Ogujiuba K and K Alehile (2011)Inclusive Growth in Nigeria: Policy Issues and Determinant

Organisation for Economic Co-operation and Development (2012) Promoting Inclusive Growth: Challenges and Policies. Paris

Organisation for Economic Co-operation and Development (OECD, 2014) All on Board Making Inclusive Growth Happen. www.oecd.org/publishing/corringenda

Organisation for Economic Co-operation and Development (OECD, 2009) Promoting Pro-Poor Growth Employment

Ortiz I. and Cummins M. (2011) Global Inequality: Beyond the Bottom Billion. A Rapid Review of Income Distribution in 141 Countries. UNICEF Social and Economic Policy Working Paper, 2011

Potts R. (2012) Social Protection in South Africa: Curing or Causing Poverty. Penn State ofInternational Affairs, p.74-92

Samans R, J Blanke, G Corringan. and M Drzenniek. (2015) Benchmarking Inclusive Growth and Development. World Economic Forum Discussion Paper 2017

Sembene D. (2015) Poverty, Growth and Inequality in sub-Saharan Africa: Did the Walk Match the Talk under PRSP Approac? IMF Working Paper 15/122

Son HH and N Kakwani (2004) Economic Growth and Poverty Reduction: Initial Conditions Matter. International poverty Centre, UNDP, Working paper number 2

United Nations Development Programme (UNDP, 2014) Accelerating Inclusive Growth for Sustainable Human Development in Ethiopia. National Human Development Report, Addis Ababa, Ethiopia, 2014

United Nations Development Programme (UNDP, 2011) Consultation on Conceptualizing Inclusive Growth. New Delhi, India 24-25 October, 2011

World Bank (2018) World Bank Development Indicators

Zhuang J and I Ali. (2010) Poverty, Inequality, and Inclusive Growth in Asia: Measurement, Policy Issues, and Country Studies. DOI:10.7135/UPO9780857288066.003 